
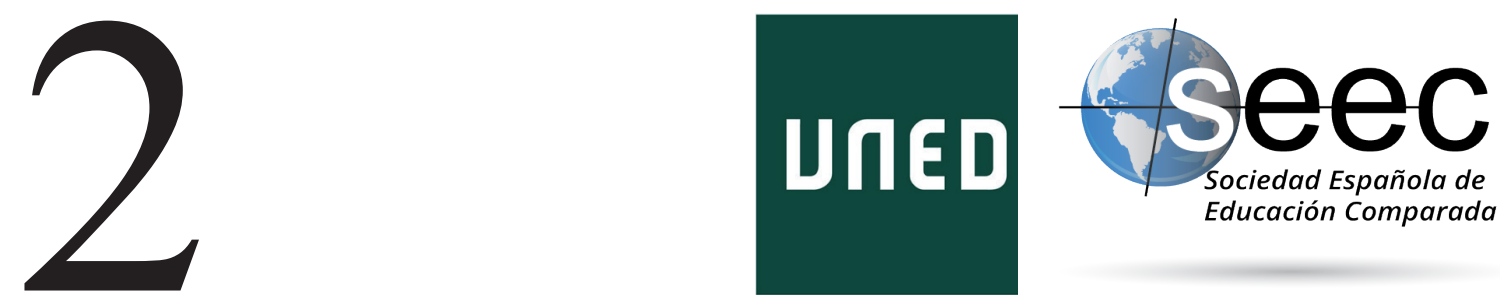

\title{
Religion, schooling and the state: negotiating and constructing the secular space
}

\author{
Religión, escolarización y Estado: \\ negociando y construyendo el espacio secular
}

\author{
Leslie Bash*
}

DOI: $10.5944 /$ reec.33.2019.22327

\author{
Recibido: 12 de julio de 2018 \\ Aceptado: 7 de enero de 2019
}

\begin{abstract}
*LeSLIE BASH holds an Honorary Readership at the UCL Institute of Education, University College London where he is Director of the International Centre for Intercultural Studies. In addition, he is also Reader in Jewish Education at Leo Baeck College, London, and is currently vice-president of the International Association for Intercultural Education. He was previously based at Anglia Ruskin University where he was Principal Lecturer in Education and director of the Doctorate in Education programme. Having graduated in sociology and having obtained a teaching certificate he subsequently taught social studies in London secondary schools and, at the same time pursued postgraduate studies in education, eventually gaining a $\mathrm{PhD}$ in comparative education. He has published widely, having authored, co-authored, edited and contributed to a number of volumes, as well as journal articles, in urban, international and intercultural education. Among his research interests are religion, the state and education; diversity, equity and education; intersectionality and cultural issues in education. Datos de contacto: E-mail: L.Bash@ucl.ac.uk
\end{abstract}




\begin{abstract}
As a prelude to the paper it should be stated that its genesis originates in conference presentations delivered on two separate occasions to two separate audiences. The first was to a mixed group of teacher educators, Roman Catholic priests and nuns, as well as others from diverse religious traditions, at a one-day conference on religion and pluralism held in Dublin, Republic of Ireland. The expressed focus for this conference was 'inter-faith' but with the addition of a secular dimension. The second presentation was to an international group largely comprised of comparative education scholars in Glasgow, Scotland. Although the two presentations were broadly similar in content the Dublin paper had a distinct orientation. Given that the publicly-funded Irish school system was characterised by a strong involvement of religion (Department of Education and Skills, 2017) - in particular, that of the Roman Catholic Church, the dominant tradition in that country - the Dublin presentation pursued an approach which sought to widen the educational agenda. Specifically, it focused upon the continuing discussion concerning the role of secularity in school systems where confessional approaches to religion were sanctioned by the central state. On the other hand, the Glasgow presentation was more 'academic' in tone, seeking to re-position secularity and religion in a non-oppositional relationship which was, in turn, argued to be functional for 21st education systems.
\end{abstract}

Key Words: Comparative Religions; Comparative Education; Secular space

\title{
Resumen
}

La génesis de este artículo se origina en dos presentaciones en diferentes conferencias para dos audiencias diferentes. La primera fue para un grupo mixto de educadores de maestros, sacerdotes y monjas católicos romanos, así como otros de diversas tradiciones religiosas, en una conferencia de un día sobre religión y pluralismo celebrada en Dublín, República de Irlanda. El enfoque expresado para esta conferencia fue «interreligioso» pero con la adición de una dimensión secular. La segunda presentación fue para un grupo internacional compuesto principalmente por académicos de educación comparada en Glasgow, Escocia. Aunque las dos presentaciones eran muy similares en contenido, el documento de Dublín tenía una orientación distinta. Dado que el sistema escolar irlandés financiado con fondos públicos se caracteriza por una fuerte participación de la religión (Departamento de Educación y Habilidades, 2017), en particular, la de la Iglesia Católica Romana, la tradición dominante en ese país, la presentación de Dublín siguió un enfoque que buscaba ampliar la agenda educativa. Específicamente, se centró en la discusión continua sobre el papel de la secularidad en los sistemas escolares donde el estado central sancionaba los enfoques confesionales de la religión. Por otro lado, la presentación de Glasgow fue más «académica» en tono, buscando reubicar la secularidad y la religión en una relación no enfrentada que, a su vez, se argumentó, que era funcional para los sistemas de educación del siglo XXI.

Palabras clave: Religiones comparadas; Educación Comparada; Espacio secular 


\section{Introduction}

As a prelude to the paper it should be stated that its genesis originates in conference presentations delivered on two separate occasions to two separate audiences. The first was to a mixed group of teacher educators, Roman Catholic priests and nuns, as well as others from diverse religious traditions, at a one-day conference on religion and pluralism held in Dublin, Republic of Ireland. The expressed focus for this conference was 'inter-faith' but with the addition of a secular dimension. The second presentation was to an international group largely comprised of comparative education scholars in Glasgow, Scotland. Although the two presentations were broadly similar in content the Dublin paper had a distinct orientation. Given that the publicly-funded Irish school system was characterised by a strong involvement of religion (Department of Education and Skills, 2017) - in particular, that of the Roman Catholic Church, the dominant tradition in that country - the Dublin presentation pursued an approach which sought to widen the educational agenda. Specifically, it focused upon the continuing discussion concerning the role of secularity in school systems where confessional approaches to religion were sanctioned by the central state. On the other hand, the Glasgow presentation was more 'academic' in tone, seeking to re-position secularity and religion in a non-oppositional relationship which was, in turn, argued to be functional for $21^{\text {st }}$ education systems.

Thus, the paper attempts to reach beyond conventional polarised debates regarding the legitimacy of religion in relation to public education. Specifically, it turns on the meanings attributed to the religious and the secular and, accordingly, suggests that a comparative lens might be helpful in highlighting the limitations of an oppositional approach. In addition, the thrust of the paper rests on an underlying premise of interculturality, a premise which in this context challenges the assumed segregation of religious traditions from each other, both historically and currently.

Interculturality, as distinct from the prescriptive character of interculturalism, is used here to denote the realities of current and historical interactions between people of diverse heritages. Accordingly, interculturality can be viewed sociologically and manifested in such processes as synchronicity, hybridity and plurality. However, this not to deny the impetus given from a commitment to interculturalism which, to a large extent, has characterised the author's sustained involvement in the field of education and diversity. Interculturalism has certainly been subject to much critique (see Meer and Modood, 2011) and has often engendered responses ranging from the cynical to one of 'deja vu'. Typical are accusations of a white educational establishment immersing itself in naïve, guilt-ridden, liberalism, while attempting to guard against the apparent ills of assimilation (see: Steinberg (2001). An intersectional, intercultural discourse also signals a degree of caution in relation to certain antiracist agendas which are frequently seen to be little more than an opportunity to indulge in simplistic political rhetoric. Central to this paper is the basic premise that the role of the educator is to engender change through enabling learners, both individually and collectively, to develop knowledge and understanding in a wide range of contexts, and thereby gain an increasing degree of control over their lives. Moreover, experience in the field of social studies education has provided the foundation for the argument that if education is not concerned with enabling young people to develop critical understanding and awareness it is deficient and unsuited to the modern world. However, at the same time, a parallel background in comparative education has also encouraged the more realistic observation that state-managed mass schooling systems will always shape and constrain that process. 
As a rider, it should also be mentioned that there is an attempt, for the most part, to avoid a concentration on two areas which frequently attract public attention. The first of these areas is that of the activities of what many would designate as private 'fundamentalist' religious schools. The second is that which focuses on the impact of violent extremism and the apparent politicisation of faith. While both these areas, which at some level are sometimes perceived to be connected, arouse widespread concern and fear, often amplified by media intervention, they are judged to be a weak basis for theorisation and policy making. The central theme of the paper is at one and the same time more prosaic and more deep-seated.

At this point, it should be noted that an element in the construction of this paper is an assumption of the continuing significance of strong interrelationships between religion, mass education and the nation-state. This, in turn, is predicated upon the apparent resilience of religion as a dimension of social life which many had thought would have vanished in the wake of modernity. For such commentators, the persistence of religion is perhaps something of a curiosity in an era of apparent global modernity dominated by the fruits of science and technology (Bash, 2008). On the other hand, a more nuanced and sophisticated understanding of religion might lend a degree of caution to such a conclusion.

For example, those with a Jewish heritage background (the author's own) may not necessarily find it at all strange that a disproportionate number of contemporary scientists also appeared to have hailed from such a background, reflecting the view that the Jewish tradition was frequently challenging as far as its religious character was concerned. For many of those who wished to retain their Jewish identity - and continue to do so - religious faith, as commonly understood, was not especially relevant. Notable academics and others who have acknowledged their 'Jewishness' but who have distanced themselves from the religious dimension have included: Sigmund Freud, Franz Kafka, Marc Chagall and Albert Einstein. Still others have steered a path of "non-overlapping magisteria' (NOMA) where religion is regarded as a realm of experience quite distinct from the realm of scientific enquiry and practice (Gould, 2006). On the other hand, religious faith continues to occupy a central place in the lives of many Jewish people - and for some it reigns supreme, to such an extent that it has given rise to public anxiety that it may have a detrimental impact upon children's learning and their capacity to be adequately equipped with the skills and knowledge necessary to operate effectively in wider society (Abrams, 2015). The world of independent schools in the ultra-orthodox Jewish enclaves of North London, Jerusalem and elsewhere, gives rise to concerns as much as similar establishments allied to other traditions. Yet, such schools often appear to be beyond the reach of governments and therefore marginal to the overall relationship between religion, education and the state.

Nevertheless, from the standpoint of comparative education, there is little to challenge the observation of the fundamental role played by religion - and continues to be played - in the formation and re-formation of national education systems, from kindergarten through to the university sector. Moreover, for those who were initiated into the conventional academic subculture of comparative education it was axiomatic that the nation-state was the unit of analysis when undertaking investigations of educational phenomena. 'National character' and 'national culture' were the order of the day. The 'founding fathers' either explicitly showcased individual nations - such as Hans (1949) and King (1958) - while for others the nation was implicit. As a proviso, we are aware of 
those who undertook regionally-based comparative studies, while there were others who decided that political-economic difference and socio-economic difference was of significance, as reflected in the well-worn binaries of: communist/socialist versus capitalist and rich versus poor. The perspective taken here, however, reflects a primary concern with what still others have considered to be core issues in education, surfacing in a diverse manner in the context both of educational practice and educational policy over the past fifty years in 'Western' societies. At the beginning of that period, and as befits that era, the focus was frequently on the need to generate social awareness in schools to enable the development of critical understanding against a backcloth of consumerism and depoliticisation (see: Bash, 1976, 1981a, 1981b). Religion appeared to be a social phenomenon, at least in Western societies, which bore little relevance since it was assumed to be on an inevitable decline into obscurity.

As a consequence, the paper attempts to approach these issues in a more eclectic, dynamic manner. Here, it is important to make some initial, fairly obvious, observations. The first is the recognition that the social construction of contemporary educational reality is a process which derives from the interplay between diverse macro and micro socio-economic, political and cultural phenomena. Given the place of religion in the process this somewhat unremarkable observation masks a complexity which requires further comment. It takes a mere glance at the histories of education systems and processes across the globe to pronounce with some confidence on the centrality of religion, at both the normative and institutional levels, in the majority of those histories. These histories will reveal that education has necessarily been largely anchored in religion, variously reflected in underlying philosophies, modalities of institutional governance, together with pedagogical theory and practice. The following would seem to exemplify the commonly accepted function of religion in respect of education in Britain in the midnineteenth century:

\begin{abstract}
"It is no question of sect or dogma when a hope is expressed that religious truth, as derived from the Bible, in its plain, preceptive, and historical teaching, might still be an item of necessary instruction, since without it, it is hard to see how the character of the pupil can be formed, or the authority of the teacher upheld. Right and wrong must be maintained in a school. No minute, possibly, can pass in its curriculum without these being tested". (Melville, 1867)
\end{abstract}

While in 'late modernity' the governance of education apparently shifted to a more secular basis, especially with the exponential growth of science and technology, together with an increase in bureaucratisation, this was not a uniform process. In some cases, as with France, the governance of publicly-funded education and the control of curricula became the province of the secularised central state. In the United States, education was and is firmly entrenched as a state/local affair characterised by a softer version of secularism.

\title{
2. Religion and the public realm
}

Accordingly, this paper positions itself against a global backdrop of frequently conflicting perspectives concerning the legitimacy of religion in the public realm and seeks to engage with what may be considered to be key issues concerning the relationship 
between religion and secularity in education. Specifically, there is an attempt to offer an overview of some crucial questions concerning religion, schooling and the state as a prelude to possible research which it is anticipated might yield fresh insights into the relationship between the religious and secular dimensions of educational and communal spheres of action.

The role of religion in public life is of course constantly rehearsed. The phenomenon of religious extremism is not new. Neither is the combination of the two, but until relatively recently, such a combination appeared to be confined to the past. At least, this is how it was perceived in popular Western discourse. A comparative, historical glance suggested a convergence of social systems: while religiosity, as measured by attendance at places of worship, had been in chronic decline for over a century in many Western countries, the erstwhile Soviet Union and its satellites had apparently banished organised religion to the margins. Moreover, despite the well-documented historical relationship between religion and education across nations and regions dominated by diverse heritages, there appeared to be, in an era of 'late modernity', an unstoppable movement in the direction of secularity.

Doubtless, this has been reinforced by the view that education and religion is indeed an unholy brew, a view which prompted an earlier examination of issues connected with the engagement of religion with education. Initially presented at a conference in Granada, Spain, in 2006 and appearing in a publication, 'Changing Knowledge and Education', two years later, possible tensions between education and religion were addressed (Bash, 2008). The primary task, it seemed, was to attempt to clarify the conflict between religion, on the one hand, and education in a modern liberal democracy on the other. It has long been apparent that the claims to knowledge which each was purported to have were not wholly compatible. Despite his often uncompromising tone the evolutionary biologist, Richard Dawkins (2006), together with his supporters, claimed with little fear of contradiction, that science sought explanations on the basis of a combination of rational, analytical thinking and empirical observation subject to public verification, while religion concerned the transcendent and thus not subject to the same tests. While, for the most part, that claim continues to be persuasive, there is at the same time an alternative argument which does not consider the realm of religion to be entirely antithetical to the quest for worldly knowledge and, by extension, to the realm of education. However, this would seem to depend on the extent to which religion is prepared not merely to tolerate the secular world but also to view secularity as a positive frame of reference for intercultural engagement, synchronicity and learning. For some religious traditions this may be a step too far - but for others it may be, as it were, a route to their salvation, especially those which have sought reconciliation with societal change. The following by Gita Sahgal lends support for this view (although, in the context of this paper, the preference is for 'secularity' rather than 'secularism'):

"When I say secularism, I do not mean the absence of religion but rather a state structure that defends both freedom of expression and freedom of religion or belief, where there is no state religion, where law is not derived from God and where religious actors cannot impose their will on public policy. A secular state does not simply limit religion, it also maintains the essential right of religious freedom as a duty not a favour. This means that it defends the freedom to worship and the right to maintain churches and temples, unhindered, and also defends minorities from attack". (Gita Sahgal, 2013) 
Following this, much depends on the way in which secularity is conceptualised since, no less than religion, it is capable of being defined in diverse ways but, for the most part, secularity and religion are frequently viewed as mutually exclusive. The argument of this paper is based on the case for a secularity which is seen as compatible with the religious realm in societies which claim to be open, liberal democracies. This case is contingent upon a more cautious approach both to secularity and to religion where secularity denotes a space which facilitates the free articulation and interchange of knowledge, ideas and beliefs - and, most importantly, a space structured on the basis of equality. The secular space, defined in this manner, cannot operate effectively where there is unequal power, cultural domination and subordination, and hidden agendas. More constructively, the secular space is in a state of continual configuration, defined dynamically - and ideally - in the context of mutual respect, engagement, dialogue and inclusion. It is - to employ the terminology of Ivan Illich (1973) - a convivial space, experienced democratically and largely devoid of barriers.

However, the operation of such open secularity may often appear elusive, even in the supposedly enlightened Western hemisphere. We may judge this to be a somewhat limited interpretation of history, especially when applied to the context of publicly-provided education. The reality is characterised by a degree of complexity which bears some scrutiny and, in this context, reference may be made to one of the key symbolic events with regard to the legitimacy accorded to religion in the sphere of educational policy in the American public arena. This was the 'Scopes Monkey Trial' of 1925 which was referenced at a seminar presentation by James W Fraser (2016). Those whose knowledge of the trial was derived more from the Hollywood movie 'Inherit the Wind' than from historical sources were intrigued to discover that there was more to the case than appeared on the surface. The trial itself concerned the state of Tennessee's ban on the teaching of evolutionary theory in schools, with Mr Scopes, the defendant who had taught evolution in defiance of the ban, surprisingly desiring a conviction with the expectation that it would result an eventual appeal to the US Supreme Court. The hope was that the court would deem the ban on the teaching of evolution to be unconstitutional and so have positive ramifications across the entire United States. However, in addition to this, it needs to be noted that the major protagonist on the prosecution side, while taking a fundamentalist, Christian, anti- evolutionist stance, was no simple 'Bible Belt' reactionary. On the contrary, he was apparently a left-wing radical politician who observed the dangers of the anti-egalitarian implications of evolutionary theory - wrongly, perhaps, when set against contemporary scientific thought - especially when observed in the context of eugenics with its now commonly accepted racist and classist connotations.

However, the long-term consequences for the relationship between religion and publicly-provided education in the United States were significant. Stephen Jay Gould noted that in 1999:

"...the Kansas Board of Education voted six to four to remove evolution, and the big bang theory as well, from the state's science curriculum. In so doing, the board transported its jurisdiction to a never-never land where a Dorothy of a new millennium might exclaim, 'They still call it Kansas, but I don't think we're in the real world anymore'.....". (Gould, 2006)

Yet, it was the real world for a majority of Americans, as indeed it has been for the majority of the global population. Evolutionary theory and other associated ideas could 
be marginalised as the affected meanderings of atheistic academia. The somewhat overplayed narrative which privileges the regional divide in the United States - between the godly mid-west and the largely godless east and west coasts - nonetheless carries a sufficient degree of persuasiveness such as to provide something of a descriptive model to apply elsewhere. The legitimacy of religion as an essential, if not a defining, aspect of public life remains as much a part of rural Kansas as it does in rural Anatolia. Of course, we might wish to characterise such a distinction in terms of the obduracy of 'tradition' in the face of modernity. While late $19^{\text {th }}$ and early $20^{\text {th }}$ century social scientists - Durkheim (1997), Weber (Gerth and Mills,1946), Marx (Bottomore and Rubel, 1956) - in different ways assumed the inexorable triumph of 'modernity' they inevitably had to come to terms with social lag. Gemeinschaft und Gesellschaft, to use Tonnies' (1955) terminology, appear to be able to exist side by side as social life based on 'tradition' and close kinship ties battles against the encroachment of patterns of human engagement grounded in contractual fleeting relationships.

Of course, those who find difficulty with positivistic, linear models of change might find a worldview which privileges the intersectionality of the traditional and the modern, or, in the case of this presentation, the religious and the secular somewhat more acceptable. Or, more specifically, the main focus here is the intersectionality of religion and secularity in the dynamics of national educational systems and, accordingly, attempt to deconstruct the binary division between the two in an attempt to demonstrate that there have been, historically, syncretic and dialogic processes.

\section{Interrogating the religious and the secular}

As far as the modern nation-state is concerned religion appears to be a relatively tightly drawn concept. Insofar it is to be seen as a significant dimension of the social system a religion would need to possess a certain degree of power, if not authority. Thus, Western states might safely dismiss Scientology as a marginal sect or cult, while the conventional variants of Christianity and what is perceived as mainstream Islam are accorded legitimacy; indeed, the question as to what actually constitutes a religion may vary from one jurisdiction to another. Likewise, what constitutes the secular equally invites interrogation. For some, it is epitomised by a strict separation of religion from the activities of the state and, by implication, from public life altogether, while for others, the secular indicates a looser, inclusive concept, worldly but not necessarily anti-religious.

Let us pause to consider the manner in which publicly-funded school systems have sought to incorporate and/or maintain the religious dimension of education in the face of increasing secularisation. There are those states which have adopted legalistic positions, often enshrined in constitutions or in laws which have constitutional implications and, as such, are able to be examined with relative ease. Nonetheless, the complexities surrounding the relationship between religion and education in such systems can be quite forbidding and open to varying interpretation. States as diverse as Iran, Israel and Greece exemplify the constitutional centrality of religion and, by extension, the religious character of education. Collective identity and nationhood in these case are inextricably bound up with, and defined by, a specific religious tradition. However, in the case of Israel, there are complexities and tensions which make any kind of analysis difficult: the divisions and diversity within the Jewish population; a large Muslim minority; plus Christians, Druze and others. 
By way of contrast, as is well-known, secularism rather than religion is considered to be one of the foundations of the modern French state. In the case of France, secularism is enshrined in the notion of laïcité, a highly politicised notion, with its revolutionary and Napoleonic genesis. Laïcité is a fiercely defended cornerstone of public policy in contemporary France - a correlate of liberté, egalité et fraternité - one outcome of which has been, inter alia, the ban on the wearing of the burqa in public. In present-day France, the secular space may be regarded as an exclusive arena as it attempts to exclude all trappings of religious expression. The result, many would argue, is that it unfairly discriminates against minoritised populations for whom religious expression is an integral constituent of ethnic and cultural identity.

Recently, Myriam Hunter-Henin, a comparativist in the field of law at University College, London, has written incisively on this theme, highlighting some of the tensions and contradictions existing between the apparent egalité of the burka ban, established in 2010, and its consequence of a denial of liberté, and in so doing challenge a fundamental premise of the modern French state:

"The eradication of difference that is sought by the new law is alien to secularism which even in its most virulent forms is designed to manage rather than deny diversity of beliefs. Nor is the new law a crusade for feminism. The ideal and abstract female image it defends does not support the dignity of veiled women but seeks to protect the comfort of the majority". (Hunter-Henin, 2012. p. 617)

In any case, argues Hunter-Henin, such an interpretation of laïcité is based upon sociological misreading, in that the donning of the veil or burka is frequently an expression of:

"... a personal quest for meaning and identity rather than by an extremist religious position...". (ibid. p. 617)

Or, it may function as a means of expressing commonality with others who view themselves as coming from the same cultural tradition, but with little or no connection with the religious dimension. The veil or burka may indeed have acquired what might be termed a neo-secular status in the context of style or fashion, much in the same way that the Jewish mystical practice of Kabbalah, in becoming secularised, has been taken up by those with no connection with Judaism. For this reason, drawing upon the example of France, I shall argue for a more careful consideration of the relationship between religion, state and education.

What may possibly be at the heart of the matter is a conflation of 'producers' with 'consumers' and a misguided conception of social order. We might wish to view the 'producers' in this context as agents of the state charged with the supposed responsibility of managing the social order so as to ensure the optimal outcomes for the population as a whole. Consequently, state agents arguably have an obligation to act in a manner which does not require adherence to 'universalistic' modes of behaviour if particularistic acts do not threaten the social order. Here, liberté may trump egalité (although Balibar has attempted to navigate a way through this age-old tension with his neologism of egaliberté ascribed to the necessary conditions for the attainment of citizenship).

Those living at the margins of French society, finding themselves in a structural position of being both feared and the object of fear, unsurprisingly retreat into constructed ethno/religious identities, further reinforcing segregation in a society which has hitherto 
failed, at the political institutional level, to fully acknowledge its historic cultural diversity. (It is plausible, though by no means incontrovertibly the case, that this was an element in attacks which took place in French cities in recent years.) At a more hidden, subtler level, some might argue that laïcité represents a deeply rooted collective self-image which belies the self-satisfaction conjured up by the spirit of post-Napoleonic France. The apparent anti-clericalism of laïcité is not perceived to extend equally to all religious traditions and that Catholicism retains dominance, if somewhat submerged, within French national culture.

The situation in Britain, on the other hand, suggests that superficially at least it does not hold with the strictures of laïcité, viewing it as a peculiarly Gallic notion. However, this might be observed as a less than justified position of holding to a superior view of the rigidity of post-revolutionary France. It is a view emanating from some of the liberal intelligentsia of English academe and, more often than not, one which has not sought to question historic responsibility for the consequences of colonialism and neo-colonialism, not least, of course, in the case of Ireland. Indeed, it might be argued that is a degree of collective self-satisfaction with the manner in which England specifically (rather than Britain as a whole) has engaged with religious diversity since the Reformation. Indeed, the Church of England is sometimes portrayed as some kind of semi-secular space in which all can participate, partly a consequence of its official established status, and partly because adherence to its customs appears - to some - to require relatively little in the way of personal commitment or sacrifice, certainly when compared with other Christian traditions.

In England, as might be expected, there has been a continuing 'muddling through' with the established church (Church of England) sometimes having an active role in institutional and curricular governance, sometimes a relatively nominal role and at other times no role at all. Meanwhile, the general perception has been that the state at both central and local levels has conventionally negotiated an educational settlement, in respect of tax-funded schools, with the aim of meeting the religious demands of diverse groups as long as such demands were not seen as extreme, fanatical or fundamentalist. Accordingly, in addition to Church of England schools, a considerable number of Roman Catholic schools, a lesser number of non-conformist Protestant schools and a few Jewish schools could be accommodated in this manner. More importantly, fully tax-funded non-denominational 'secular' schools were expected to have a vaguely 'Christian' character. More recently, other so-called 'faith' groups (to use the conventional but somewhat problematic British terminology) have decided that they wish to have a slice of the tax-funded educational action. I shall return to the UK context a little later on in the paper (we might note, as an aside, that in recent times a previous chief rabbi of the UK attended a Church of England secondary school in North London.) At the same time it might also be argued that Anglicanism, however benignly inclusive it might appear on the surface, had - and possibly continues to have - ramifications in relation both to the curriculum and to school governance. It may also be seen in the broader context of the control and legitimation of educational knowledge which characterised British imperialism of the $19^{\text {th }}$ and early $20^{\text {th }}$ centuries (together with other European powers), producing elitist systems which negated the legitimacy of non-Western knowledge traditions. Until the demise of the old empires secular and religious power coincided to some degree in the way in which elitist education systems operated, with a substantial amount of sub-contracting to missionary bodies. The 
contrast with the post-imperial context and the seemingly rapid advance of Islam as a world religion in many of the ex-colonies, alongside the parallel growth of educational secularism in Europe and North America, and its incursion into the field of educational provision and the curriculum, caught Western academics somewhat unprepared.

\section{Secularism and secularity}

Thus, there is a proposal to make a distinction between secularism and secularity. Here, secularism is held to be an ideology which frequently operates rhetorically. It is a banner to wave in the course of conflict between 'tradition' and 'modernity', while secularity points to a dimension of social relationships and institutional behaviour. It is the latter which lends itself to an investigation into the extent to which the secular and the religious might co-exist. At this point, it is suggested that there is a case in which secularity can be seen to be compatible with the religious realm - at least in those societies which claim to be open, liberal democracies.

In this way, there is an attempt to move the narrative from one which focuses on religion as a machine which processes individuals in defining their actions and their very existence and which, as a consequence, views engagement between peoples as highly problematic. It is problematic because such engagement is perceived ultimately to result in a compromise - possibly betrayal - of principles and of particularistic behaviours. The alternative narrative - drawing on the lexicon of economics - speaks of religion, as with culture in general, as a resource. This narrative is premised on the primacy of open educational discourse which is, by definition, intercultural and therefore at variance with those discourses which privilege particularism in 'culture' and confessional approaches to religion.

\section{Constructing the secular space}

As a consequence, the paper shifts from a systemic approach to one which focuses more on patterns of interaction. So, in attempting to navigate through the intersection of religion, schooling and the secular space it is possible to consider some underlying issues regarding the construction of the secular space as a defining characteristic of classrooms. The first is the question of a redefinition of the relationship between the state and the structures and processes of education such that it does not - either explicitly or tacitly - assume the hegemony of any one particular religious tradition. Secondly, there is the question as to whether the state, through the implementation of policy at all levels, needs to privilege intercultural engagement in the creation of the secular space as a prime characteristic of educational practice. It might be assumed that such engagement is neither dependent upon the presence of minoritised children or children of a so-called migrant origin - 'visible' or otherwise - nor, in the context of this paper, of the presence of those who adhere to minority religious traditions - or, indeed, to no religion at all. Thirdly, there is the issue of inclusiveness of educational practice where inclusiveness is not defined conventionally in terms of the need to ensure all learners are formally integrated into the classroom. Rather the issue is to be seen in terms of the discursive nature of educational practice and thus challenges the assumption that the secular space can be created solely on the basis of non-discriminatory, equal opportunities rhetoric. 
A focus on the discursive nature of educational practice suggests that the creation of the secular is to be found in the process rather than in the product and that one way of looking at this process is to see it as grounded in what the philosopher and sociologist, Jurgen Habermas, refers to as communicative action. For Habermas, communicative action refers to:

\section{"...those social interactions in which the use of language oriented to reach understanding takes on a co-ordinating role ..." (Habermas, 2008, p. 53).}

We are well aware that language is a significant, complex, rule-governed means of symbolic interaction between human beings. Thus, in social interactions, the way in which language is used to undertake this coordination role pre-supposes an ascription of some kind of rationality to the 'other' which might be considered as somewhat problematic for an arena in which religious orientations are present. The point here is that effective communication between individuals is possible if the space is freely constructed on the basis of equity where there exist some basic rules, implicit in the manner in which communication is undertaken

Communicative action is enshrined in Habermas' (2000, 97-99) classic notion of the ideal speech situation. Although Habermas has since modified his ideas I consider that the notion of the ideal speech situation still has utility, especially insofar as it refers to discursive reasoning. In particular, in the field of intercultural education, we encounter continual disputation: claims and counter-claims in relation to rights, ownership, privilege, cultural superiority and inferiority, linguistic dominance and subordination, religious hegemony, and so on. Truth claims in these contexts are highly problematic and cannot be settled in a conventional pedagogical manner - if at all. Thus, in offering a critique of Habermas, no amount of assertion grounded in 'evidence' however convincing, will necessarily shift opinion and attitude. Therefore, we must look at the nature of the discourse itself to discern the possibility of cognitive and/or affective change among its participants i.e. the manner in which the communicative process reveals a process of reasoning.

So, here, we are talking about both cognitive and affective change which I argue are central for the secular space in education. To what extent can discourse grounded in a process of reasoning have an impact upon affective change, especially when viewed in the context of a web of diverse religious loyalties? Very young children are largely ill-equipped in this arena where "facts' are largely grounded in taken-for-granted truths imbibed at an early age. Developmental theory derived from Piaget and Kohlberg might give some guidance regarding preparedness for the kind of dispassionate engagement required for a Habermasian ideal speech situation. More generally, however, there is an awareness of the limits of the power of reasoned discourse. It may be judged that Habermas has been correctly taken to task for over-emphasising philosophical reasoning and downplaying the role of rhetorical persuasion in discursive interaction, especially if the process supposedly engages hearts as well as minds.

The central issue for education is the extent to which the relationship between religion and the state impinges upon the capacity of schools to provide the secular space which this paper has been attempting to outline. A dominant religious tradition which, at the very least has the ear of the state and, in some cases, is an integral part of the state apparatus will assume a privileged position, especially in the influence upon the educational narrative and agenda. In this situation, rhetorical persuasion will never be 
far from the surface and the problem is that if rhetorical persuasion gains dominance we are faced with potential coerciveness and the abandonment of the entire business of reasoned argument. And yet, the elimination of affect from discursive processes, especially in the context of intercultural education, may mean that learners are deprived of significant cultural resources which can be legitimately employed to provide sufficient ontological security to enter the arena of reasoned argument.

To put it another way, affect is significant for the provision of motivational reasons for communicative action. From Habermas' standpoint, communicative action occurs within the context of what he terms lifeworlds i.e. taken-for-granted shared cultural allegiances, and, yet, the ideal speech act is supposed to transcend such allegiances. However, one commentator, Abizadeh (2007), has made a useful attempt to resolve the reason/affect binary divide, which hindered Habermas, to enable us to engage fruitfully with intercultural pedagogy - and thus to the construction of the secular space. If a major goal of secularity in education is not simply one of disinterested - and possibly de-humanised - rationalistic discourse but one which facilitates empathic understanding (verstehen) then affect cannot be viewed as separate from the process of reasoning enshrined in the ideal speech act. On the contrary, it is a necessary condition. Thus, it is only when an empathic connection can be made between inter-subjective experience in one 'lifeworld' context with inter-subjective experience in another that communicative action occurs and reasoned discourse becomes possible.

Finally, if the premise of what has been argued throughout this paper is accepted there is the inevitable question as to what can and should be done to create the possibility of constructing this secular space. Much depends on the extent to which educational professionals - especially teachers and teacher-educators - are willing and able to exploit the opportunities which may constitute an unintentional outcome of educational policy. However, as religion continues to play a significant role in public life in diverse societies it is clear that it will also continue to have ramifications for publicly provided education. In an era of continuing migration flows new constituencies will frequently express the need for their voices to be heard with regard to education ad the way in which schools are run. As a consequence there is the understandable temptation for schools and the state at large to respond accordingly. Thus, many Church of England schools which have become largely populated by students with an entirely different religious heritage may feel the need to change their character, as did some local board schools in the east end of London at the end of the $19^{\text {th }}$ century having $100 \%$ Jewish student populations. Such schools essentially became Jewish schools all but in name - Hebrew was taught, Jewish holidays were observed, and so on. However, it has to be emphasised that this was an era of assimilationism, when all schools - whether religiously confessional or not - saw their function as ensuring a high degree of integration into the overall socio-economic order. Certainly, in London around 1900, religious difference appeared to be entirely compatible with Anglicisation.

Currently, however, in the face of challenges to the conventional structure of the nation-state, the increasingly fluid nature of population movement, together with the complex nature of the interaction between diverse religious traditions demands the adoption of an alternative perspective. Such an alternative, as this paper attempts to argue, might be the promotion of educational policies which work to ensure that schools become convivial spaces where not only are all children welcome but that they are all equally valued in what they bring to such spaces. However, policies and practices with 
regard to the place of religion in schools continue, to a greater or lesser extent and either explicitly or implicitly, in many liberal democratic societies, to protect hegemonic positions which at the same time raise larger questions concerning the role of religion in society. In this broader context such questions are to be viewed in in relation to the shifting boundaries between the public and the private realms as well as competing conceptions of social justice. For many who hold to contemporary Western democratic positions on public life there are challenges to liberal world views and the limits to such liberalism. Or, to put it another way, such challenges concern the position of secularity in those societies which are characterised as products of the Enlightenment and modernity. The secular space as a dynamic characteristic of the classroom, together with its capacity to negotiate difference, is one thing. It is quite another thing to extrapolate that to entire nation-states. As Basil Bernstein (197) famously observed, education cannot compensate for society.

\section{Conclusion: towards a research agenda}

This paper has been at a relatively high level of generality and has not sought to consider a detailed research agenda which might provide an evidential foundation for the arguments presented. However, the impetus for comparative research in this field is significant. It is insufficient to see it solely as a matter for academic deliberation; a central value-judgement is inevitable. In societies where a single religious tradition is dominant and where the institutional structure reflects that dominance it is often immensely difficult to convince policymakers that plurality and secularity have relevance in publicly-run schools. In such societies, prevailing religious traditions are viewed as non-problematic unless of course there are strains, tensions and divisions within those traditions. Minority traditions, especially when they are the outcome of earlier religious schisms, are often viewed as deviant, frequently regarded with hostility and with their adherents labelled as apostates (such was the case of the English Reformation and Counter-Reformation of the $16^{\text {th }}$ century with denunciations and judicial and extra-judicial killings on both sides).

In a country such as Israel, there is a kaleidoscopic situation: state-funded Jewish schools ('secular' and 'religious'); state-funded Arab (essentially Muslim) schools; independently funded Christian (essentially Arab) schools; independently funded 'ultraorthodox' Jewish schools; etc. Jewish hegemony is, however, taken for granted in Israel, it is, not unsurprisingly seen as the natural condition of existence. Anything else is, to say the least, somewhat odd - and given the segregated character of the school system and in Israeli society as a whole the secular space is highly restricted. Israel is certainly culturally - and religiously - diverse but intercultural engagement is sorely lacking, even within the Jewish population.

However, it is anticipated that it could provide a basis for a preliminary comparative study of debates, research, policies and practices in diverse countries. An enquiry of this nature might focus both on non-denominational 'secular' and confessional 'faith' schools involving both theoretical and empirical investigations. In addition, a consideration of historical trajectories will permit an examination of the variety of ways in which the larger issues discussed in this paper are playing out in Europe. Furthermore, such a study may indicate which of these have the potential to create a shared liberal space for calibrating social cohesion, cultural plurality and individual autonomy in what may be viewed as the secular space. 


\section{References}

Abizadeh, A. (2007). On the philosophy/rhetoric binaries. Or, is Habermasian discourse motivationally impotent? Philosophy Social Criticism, 33(4), pp. 445-472

Abrams, F. (2015). Why are orthodox Jewish religious schools unregulated? The Guardian 11 August

Bash, L. (2008). 'Faith, science and modernity: some issues for education in the $21^{\text {st }}$ century'. In: Proceedings of the 2006 Comparative Education Society in Europe Conference Berlin: Peter Lang.

Bash, L. (1981a). A comparative study of political education in England and the United States (with special reference to social change in advanced capitalist countries). (Unpublished doctoral dissertation / Unpublished master's thesis). University of London.

Bash, L. (1981b). Social Studies and Social Order. Social Alternatives, 2(1) March. University of Queensland.

Bash, L. (1976). A comparative study of the extent of societal constraints upon social studies education in England and theUnited States. (Unpublished doctoral dissertation / Unpublished master's thesis). University of London.

Bernstein, B. (1970). Education cannot compensate for society. New Society, 15, pp. 387 , 344-347.

Bottomore, T. \& Rubel M. (1956). Karl Marx: Selected Writings in Sociology and Social. Philosophy. London: Watts

Dawkins, R. (2006). The God Delusion London: Bantam Press

Department of Education and Skills (2017). Republic of Ireland. http://www.education. ie/en/ Accessed 06.04.2017

Durkheim, E. (1997). The Division of Labor in Society. New York: Free Press.

Fraser, J. W. (2016). From the Scopes Trial of 1925 to battles over intelligent design in 2015: ninety years of unresolvable American efforts to come to terms with teaching evolution in schools March. Seminar presentation, UCL Institute of education, University College London.

Gaine, C . (1987). No Problem Here. London: Hutchinson

Gaine, C. (1995). Still No Problem Here. London: Trentham Books

Gerth H., \& Mills, C. W. (1946). From Max Weber: Essays in Sociology. London: Routledge

Gould, S. J. (2006). The Richness of Life. London: Jonathan Cape

Habermas J. (2008). Between Naturalism and Religion. Cambridge: Polity Press 
Hans, N. (1949). Comparative education: a study of educational factors and traditions London: Routledge

Hunter-Henin, M. (2012). Why the French don't like the burqa: laïcité, national identity and religious freedom. International and Comparative Law Quarterly, 61(03), July.

Illich, I. (1973). Tools for Conviviality. New York: Harper and Row

King, E. (1958). Other Schools and Ours. New York: Rinehart

Meer, N.\& Modood, T. (2011). How does Interculturalism Contrast with Multiculturalism? Journal of Intercultural Studies, 9, December. http://www.tandfonline.com/loi/ cjis20 Accessed 07.04.2017.

Melville, D. (1868). The probable course of legislation on popular education, and the position of the church with regard to it London: Rivingtons

Sahgal, G. (2013). Secular space: bridging the religious-secular divide?. https://www. opendemocracy.net/5050.

Steinberg, S. (2001). Introduction: The Neo-liberal Construction of the Multi/Intercultural Conversation: It Is Not a Small, Definable World After All Counterpoints. Vol. 94 Multi / Intercultural Conversations: A Reader pp. xix-xxix. Peter Land AG http:// www.jstor.org/stable/42976757 Accessed 07.04.2017

Tonnies, F. (1955). Community and Association. London: Routledge 